\title{
PENINGKATAN KOMPETENSI GURU PGRI MELALUI PELATIHAN MELAKSANAKAN PENELITIAN SEDERHANA DI KABUPATEN JOMBANG
}

\author{
Hilda Cahyani, Sugeng Hariyanto, Achmad Suyono, Abdullah Helmy, Abdul Muqit \\ Politeknik Negeri Malang \\ hilda.cahyani@polinema.ac.id
}

\begin{abstract}
This Classroom Action Research (CAR) aims to improve the competence of PGRI teachers in Jombang Regency, East Java province. Improving teacher competence is carried out through simple research such as Classroom Action Research (CAR). Classroom Action Research (CAR) training is carried out with a cyclical strategy carried out with stages from problem identification, planning, action, observation, and reflection. Data collection techniques used in this study include observation, interviews and evaluation. The final result in this PKM is that the training provides benefits for teachers, namely it can improve teacher understanding in CAR Classroom Action Research, foster motivation in preparing CAR and implementing CAR, as well as improving school performance through increasing teacher professionalism. Therefore, it is hoped that the results of this study can be used as input for teachers in other schools as an effort to improve teacher competence through CAR Class Action Research.
\end{abstract}

Keywords: Teacher competence, simple research, classroom action research

\section{ANALISIS SITUASI}

Guru merupakan profesi atau pekerjaan yang memerlukan keahlian khusus atau profesionalisme guru. Arti dari profesional adalah sebuah profesi yang tidak dapat dilakukan oleh sembarangan orang Usman (2006). Guru memiliki peran yang strategis dalam upaya meningkatkan kualitas pendidikan sehingga ada slogan no teacher, no education yang berarti tidak ada guru, tidak ada pendidikan. Dengan kata lain guru merupakan komponen kunci dalam upaya peningkatan kualitas pendidikan dan menjadi salah satu penentu keberhasilan pendidikan, seperti membentuk watak bangsa dan mengembangkan potensi siswa dalam kerangka pembangunan pendidikan di Indonesia. Hadirnya guru pada saat ini sampai akhir zaman nanti tidak akan pernah dapat digantikan oleh teknologi secanggih apapun. Oleh karena itu, dalam melaksanakan tugas-tugas guru yang cukup komplek dan unik maka diperlukan guru yang memiliki kemampuan yang maksimal untuk mewujudkan tujuan pendidikan nasional serta kemauan untuk secara kontinyu meningkatkan kompetensinya. Dengan tugas profesional dan didukung oleh kompetensi pedagogiknya, guru berfungsi membantu peserta didik untuk belajar dan berkembang, membantu perkembangan intelektual, personal dan sosial warga masyarakat yang memasuki sekolah (Cooper, 1982).

Upaya dalam meningkatkan kualitas guru untuk menyelesaikan masalah yang dihadapi saat menjalankan tugasnya akan memberi dampak positif yaitu pertama, penyelesaian masalah pendidikan dan pembelajaran melalui sebuah investigasi terkendali akan dapat meningkatkan kualitas isi, masukan, proses, dan hasil belajar; kedua, kemampuan dalam menyelesaikan masalah pendidikan yang nyata akan semakin meningkat; dan ketiga, peningkatan profesionalisme guru. Guru profesional akan terlihat melalui tanggung jawabnya sebagai seorang guru dalam melaksanakan seluruh pengabdiannya. Guru profesional mampu memikul dan melaksanakan tanggung jawabnya kepada peserta didik, orang tua, masyarakat, bangsa, negara dan agamanya. 
Guru profesional mempunyai tanggung jawab sosial diwujudkan melalui kompetensi guru dari lingkungan sosial serta memiliki kemampuan interaktif yang efektif. Guru wajib memiliki kualifikasi akademik, sertifikasi pendidik, kompetensi, sehat jasmani dan rohani, serta memiliki kemampuan untuk mewujudkan tujuan pendidikan nasional. Kompetensi guru merupakan kemampuan dari seorang guru dalam melaksanakan kewajibankewajibannya secara bertanggung jawab dan layak. Sudrajad (2007) mengemukakan bahwa seorang guru yang inovatif, produktif, dan kreatif merupakan guru yang selalu mencari dan menemukan hal-hal baru dan mutakhir untuk kepentingan kualitas pembelajaran di kelas. Guru yang berkompenten dan profesional adalah guru yang piawai dalam melaksanakan profesinya (Syah, 2000). Guza (2008) mengatakan bahwa standar kompetensi guru meliputi empat kompetensi utama, adalah 1) kompetensi pedagogik; 2) kompetensi kepribadian; 3) kompetensi social; dan 4) kompetensi profesional. Jika diperhatikan dengan cermat maka kompetensi guru tersebut ternyata mempunyai hubungan yang saling berkaitan untuk mewujudkan kompetensi guru yang optimal.

Definisi kompetensi profesionalisme guru termuat dalam Depdiknas (2004) yakni "kompetensi profesional meliputi pengembangan profesi, pemahaman wawasan, dan penguasaan bahan kajian akademik". Guru yang memiliki kompetensi tinggi adalah orang yang memiliki kemampuan dan keahlian khusus dalam bidang keguruan, sehingga Ia mampu melakukan tugas dan fungsinya sebagai guru dengan kemampuan yang maksimal (Usman, 2006). Pemerintah saat ini telah mengeluarkan peraturan dalam upaya meningkatkan profesionalisme guru secara berkelanjutan yang menekankan bahwa pengembangan keprofesian berkelanjutan (PKB) adalah pengembangan kompetensi pendidik yang dilaksanakan sesuai dengan kebutuhan, bertahap, dan berkelanjutan untuk meningkatkan profesionalitasnya, melalui Permenpan no 16 tahun 2009. PKB ini terdiri dari tiga kegiatan, yaitu salah satunya publikasi ilmiah dalam bentuk (a) membuat publikasi ilmiah atas hasil penelitian dan (b) membuat publikasi buku

Pada praktiknya, kegiatan publikasi ilmiah dalam atas hasil penelitian bukan merupakan hal yang mudah untuk dilakukan bagi semua guru. Hal ini tidak terlepas dari permasalahan yang dihadapi oleh para guru sekarang ini yakni, banyaknya guru yang belum mengenal PTK (Graha Pusaka, 2012). Ini dikarenakan, pengetahuan tentang PTK baik yang menyangkut diagnosis dan penetapan masalah, bentuk dan skenario tindakan, maupun prosedur pelaksanaan masih sangat terbatas. Akibatya, proses kenaikan pangkat pun menjadi terhambat karena kurangnya komponen penelitian yang mestinya mereka lakukan. Hal ini wajar, pasalnya pelatihan Penelitian Tindakan Kelas yang pernah diikuti selama ini hanya sebatas memberikan pemahaman terhadap konsep dasar Penelitian Tindakan Kelas saja. Oleh karena itu, dalam upaya untuk meningkatkan kompetensi guru dalam asosiasi PGRI di Kabupaten Jombang melalui penulisan PTK, maka PKM ini disusun dengan tujuan memberikan pelatihan PTK yang sesuai dengan kebutuhan guru, melibatkan guru secara aktif dalam perencanaan, pelaksanaan, dan menilai hasil pelatihan, serta mendampingi secara intensif guru-guru tersebut hingga mampu menyusun atau menghasilkan PTK dengan baik.

\section{METODE PELAKSANAAN}

PKM ini memiliki luaran berupa pelatihan terkait pelaksanaan PTK untuk guru yang tergabung dalam APKS PGRI Jombang. Program pelatihan ini diharapkan dapat menumbuhkan motivasi guru untuk melakukan penelitian dan publikasi sebagai upaya untuk memperbaiki dan meningkatkan mutu pembelajaran. Selain itu, pelatihan 
PTK bagi guru ini juga diharapkan untuk membantu guru memperbaiki kekurangannya dalam mengajar agar berdampak pada perbaikan proses belajar siswa. Kegiatan pelatihan dalam PKM ini juga diharapkan dapat menumbuhkan budaya professional di kalangan pendidik.

Kegiatan pelatihan ini dilaksanakan secara online pada Jumat, 25 Juni 2021 melalui platform Zoom dengan kapasitas 100 orang yang terdiri dari kelompok guru yang tergabung dalam APKS (Asosiasi Profesi dan Keahlian Sejenis) PGRI Jombang. Metode pelaksanaan pelatihan yang digunakan dalam PKM ini adalah pendekatan Penelitian Tindakan Kelas (PTK) yang dibagi dalam beberapa tahapan, yakni:

(a) Perencanaan tindakan

Pada fase perencanaan, tim pengabdian melakukan pendekatan kepada APKS untuk melakukan rapat secara online mengenai rencana dilaksanakannya pelatihan. Dalam rapat ini turut hadir beberapa petinggi dari APKS Jombang yang menyambut dengan baik kegiatan pengabdian ini. Adapun rapat tersebut dilaksanakan dua kali secara online melalui platform Zoom.

Selain melakukan persiapan melalui rapat, tim pengabdian dan perwakilan APKS juga memiliki WhatsApp group untuk berkoordinasi dan berdiskusi mengenai persiapan pelatihan.

(b) Pelaksanaan tindakan

Pelaksanaan dalam penelitian tindakan adalah dengan menerapkan apa yang telah direncanakan pada tahap satu, dalam hal kegiatan PKM ini adalah dilaksanakannya kegiatan pelatihan PTK kepada kelompok guru yang tergabung dalam APKS PGRI Jombang.

(c) Observasi

Observasi merupakan alat untuk memotret seberapa jauh efek tindakan telah mencapai sasaran. Pada PKM ini, tahapan observasi dilakukan bersamaan dengan pelaksanaan kegiatan pelatihan PTK.

(d) Refleksi
Refleksi adalah kegiatan untuk mengemukakan kembali apa yang telah dilakukan. Dalam PKM ini, tahapan refleksi dilaksanakan sebagai evaluasi atas pelaksanaan kegiatan pelatihan yang telah dilaksaakan.Evaluasi ini dilaksanakan pada akhir kegiatan pelatihan dengan membagikan open kuesioner kepada peserta.

\section{HASIL DAN PEMBAHASAN}

Pelatihan PTK untuk guru yang tergabung dalam APKS PGRI Jombang yang merupakan tujuan dari PKM ini telah berhasil dilaksanakan dengan kerjasama yang baik antara tim dari APKS PGRI Jombang dan Pengabdian POLINEMA.

Pembagian tugas dalam kerjasama antara dua tim ini meliputi pembagian tugas untuk pembawa acara, moderator, membuat undangan untuk peserta, membuat daftar hadir untuk pemberian sertifikat.

Undangan dibuat dalam bentuk poster yang dibagikan dalam aplikasi WhatsApp.

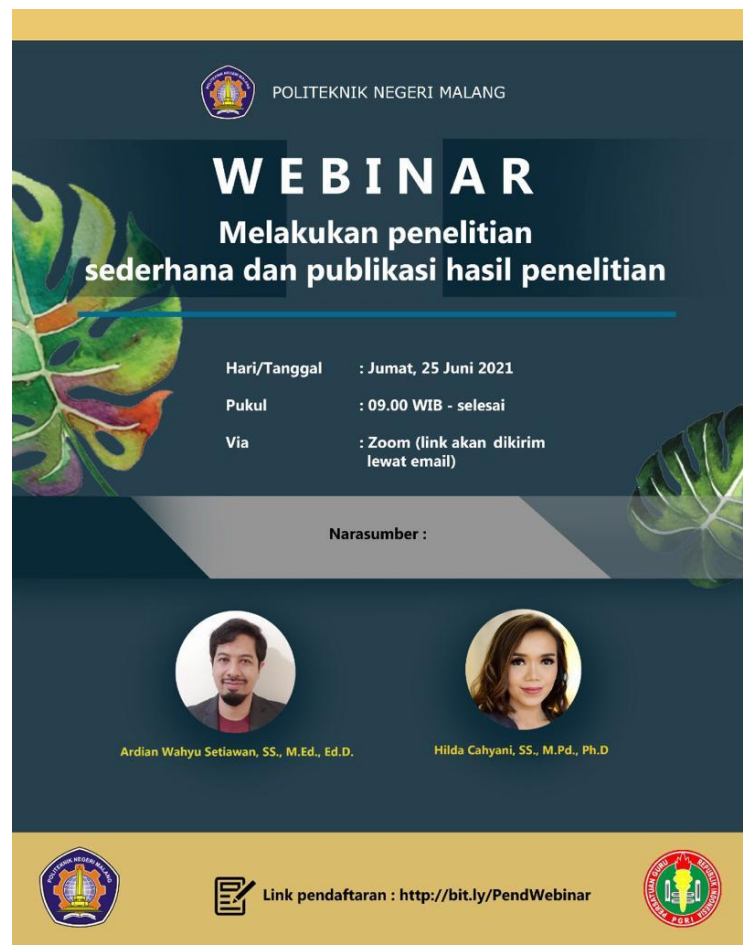

Gambar 1. Undangan Webinar

Melakukan Penelitian Sederhana dan Publikasi Hasil Penelitian 
Sebanyak 100 guru AKPS PGRI mendaftarkan diri untuk mengikuti kegiatan pelatihan PTK melalui link registrasi: http://bit.ly/PendWebinar. Namun, hanya 80 orang terdata hadir dalam kegiatan pelatihan yang telah dilaksanakan.

Pelaksanaan kegiatan pelatihan PTK online ini dimulai pada pukul 08.00 WIB dengan peserta terlebih dahulu masuk dan menunggu kegiatan di mulai dalam ruang Zoom. Kemudian, acara pelatihan dibuka oleh MC pada pukul 08.30 WIB, yang dilanjutkan dengan kegiatan menyanyikan lagu Indonesia Raya, Pembacaan doa, Pembukaan oleh pimpinan APKS. Penyampaian materi oleh tim Pengabdian terbagi dalam 2 sesi. Sesi pertama dimulai pada pukul 09.00 WIB sementara sesi kedua dimulai pada pukul 13.00 WIB. Kegiatan pelatihan ini diakhiri dengan penutupan pada pukul 14.30 WIB.

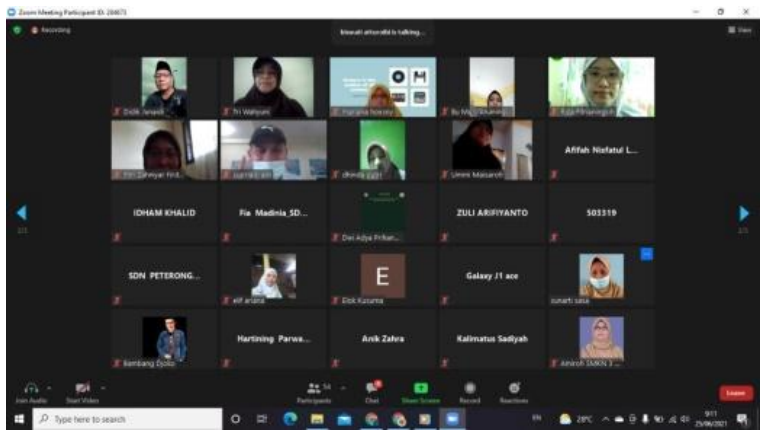

(a)

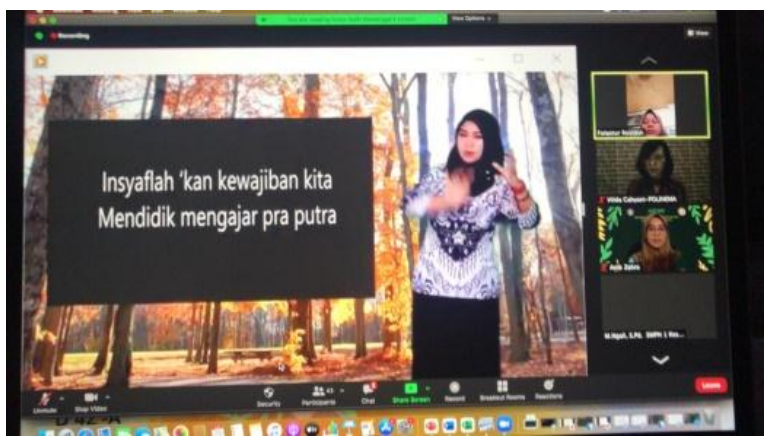

(b)

Gambar 2(a), (b). Pelaksanaan Kegiatan Webinar Melakukan Penelitian Sederhana dan Publikasi Hasil Penelitian
Pelaksanaan kegiatan pelatihan PTK ini melibatkan kerjasama yang baik antara pengusul kegiatan dan mitra. Tim pengusul, yakni tim Pengabdian POLINEMA menjajaki kerjasama dengan mitra yaitu APKS PGRI. Dengan melakukan kerjasama yang berbasis mutual ini, kegiatan ini berjalan dengan baik dan lancar. Para peserta kegiatan pelatihan, selain mendapatkan pengetahuan mengenai PTK, juga mendapatkan luaran berupa sertifikat pelatihan mengenai bagaimana melakukan penelitian tindakan kelas dan melaporkan hasil penelitian.

\section{KESIMPULAN}

Dari kegiatan pelatihan PTK yang telah dilaksanakan oleh tim Pengabdian dapat disimpulkan bahwa peserta cukup antusias dalam kegiatan pelatihan PTK yang diberikan. Namun, terbatasnya waktu kegiataan tidak dapat mengakomodasi pemateri/ narasumber untuk menjawab seluruh pertanyaan dari peserta. Selain itu, keterbatasan waktu juga menyebabkan pelatihan ini membutuhkan kegiatan tindak lanjut berupa pendampingan penelitian serta publikasi agar peserta dapat secara riil mengaplikasikan pengetahuan yang telah mereka peroleh dalam pelatihan. Kemudian, adanya peserta yang tidak hadir dalam kegiatan pelatihan, meskipun telah mendaftar, sebanyak 20 orang, perlu menjadi perhatian untuk pelaksanaan pelatihan selanjutnya, tentang pentingnya memberikan pengingat atau reminder kepada peserta yang telah melakukan registrasi agar tidak lupa untuk mengikuti program pelatihan.

\section{DAFTAR PUSTAKA}

Cooper, A. (1982). World of logotype (Annual). New York: Art Direction Book Company.

Direktorat Pembinaan Penelitian dan Pengabdian Kepada Masyarakat . (2004). Panduan Penataran dan Lokakarya Penelitian Tindakan Kelas 
Bagi Dosen LPTK se-Indonesia. Solo: Dikti-Diknas.

Graha Pustaka. (2012). Penelitian Guru Minim LIPI: Guru Kekurangan Waktu Meneliti Karena Mengajar, diakses pada grahapusaka.blogspot.com pada tanggal 13 Agustus 2018.

Guza, A. (2008). Himpunan Permendiknas Tentang Standar Pendidikan dan Tenaga Kependidikan. Jakarta: Asa Mandiri.

Sudrajad, A. (2007). Kompetensi Guru dan Kepala Sekolah. diakses dari www.akhmadsudrajad07.wordpress.com pada tanggal 12 Agustus 2018.

Syah, M. (2000). Psikologi Pendidikan dengan Pendekatan Baru. Bandung: Remaja Rosdakarya.

Usman, M. U. (2006). Menjadi Guru Profesional. Bandung: Remaja Rosdakarya. 